УДК 338

DOI: 10.17277/voprosy.2016.04.pp.115-120

\title{
REINTERPRETATION OF THE VICISSITUDE OF PLANNED ECONOMY
}

\author{
Sai Xiaoxu \\ School of Economics, Shandong Normal University, Jinan, China \\ Reviewed by Doctor of Economic Sciences, \\ Professor N. V. Zlobina
}

Keywords: incentive mechanism; information mechanism; Planned economy; planners' rationality.

\begin{abstract}
In China, most studies examine drawbacks of the planned economy with the emphasis on descriptions of the economic system, such as the indistinction between government and enterprise, the ignorance of the law of value, the serious equalitarianism in distribution and so on, which shows some limitations. From the perspectative of modern economics, the article does a comprehensive reinterpretation of the vicissitude of the planned economy from three dimensions: information mechanism, incentive mechanism and planners' rationality.
\end{abstract}

Objectively speaking, post-war countries which implemented centralized and planned economy system have experienced a period of prosperity and development. However, good times don't last long. As time goes by, with the change of external factors disadvantages of conventional system have appeared. In many socialist countries, the economy development converted from rapid growth to relative slow speed, even some serious difficulties arose. Chinese variation tendency of economic development is the same as other socialist countries. As for planned economy, there is a sharp contrast between initial success and later failure. It is a confusing question why the same economic system has represented such a different effect in just a few decades. Chinese economists have provided explanation from the perspective of political economy, but to a great extent, it is just for the description of system phenomenon. Thus, it is necessary for us to search and try another method from the perspective of modern economics and to re-interpret the vicissitude of planned economy.

Current Interpretation of the Vicissitude of Planned Economy and its Deficiency. After the reform and opening-up, Chinese theoretical field has gradually understood that both planned economy and market economy are

Сай Сяосюй - профессор экономического института, Шаньдунский педагогический университет, e-mail: saixxw@sina.com., г. Цзинань, Китайская Народная Республика. 
merely a way of resource allocation. There are various disadvantages and defects in planned economy:

1) the government performs direct management on corporations, which will integrate the government administration with corporations. The production and operation of corporations suffer a setback in enthusiasm, activeness and initiative;

2) it ignores the effects of commodity economy and the law of value, which will cause products' poor quality, slow upgrade, high material consumption and low economic benefits;

3 ) the serious phenomenon of equalitarianism in distribution is not beneficial to arouse employee's initiative and self-responsibility;

4) it controls economy based on departments or regions. The segmentary economy cuts off the internal connection of socialized mass production;

5) due to wide covering range of economic plans, the government suffers a lot from diverse and trivial affairs. Inevitably, the subjectivist and bureaucracy emerge, which will cause economic sluggish and serious decision-making errors.

6) ownership structure tends to simplify. The forward system will not improve the development of social productivity. On the contrary, it will impede it [1].

The interpretation of planned economy mentioned above covers a wide range and possesses realistic explanation power. Even so, it still has two defects in following two aspects:

1) the lack of clear understanding on the defect and its basic reasons of planned economy. The 6 disadvantages of planned economy mentioned above are not so much the internal defects as inevitable phenomenon caused by the internal defects of planned economy. Taking the integration between government and corporation and mandatory plans as an example, planned economy actually possesses its own internal logic. Planned economy can allocate social resource by mandatory plans, which depends on two premises: the one is that the central government departments must rely on and utilize the mechanism of administrative order to gather all social resources to the central government departments which also take charge of their centralized allocation. Meanwhile, the plan issued by central government should possess the property of order which is required for various departments, regions and corporations to implement. Otherwise, the plan is just a worthless piece of paper and the plan economy cannot perform. The other is that the implementation of planned economy must take relevant corporations as micro-foundation. This kind of corporation cannot have autonomous right and canny take self-interest into consideration. If not, the corporations will be entitled to modify a plan, even they choose not to implement the plan. As a result, the plan is just a worthless piece of paper and the plan economy cannot perform [2]. Therefore, under the planning system, striving for autonomous rights or self-interest for corporations and trying to convert mandatory plan to guiding plan will not overcome the disadvantages of planning system and improve economic benefit, on the contrary, it will cause dislocation due to the damage to logic unity of planned economy. It has been proved in results of socialist countries' reform on conventional system over the decades;

2) It is not unreasonable to analyze the reasons for the lack of economic vitality in socialist countries under planning system from those 6 aspects mentioned above. However, it cannot provide a definite interpretation on such a 
great power of planned economy in initial implementation and cannot give a convincing explanation on how the conventional system rises and falls.

Reinterpretation from the Perspective of Modern Economics. Essentially, planned economy organizes the whole society as a single large factory, in which central planning authorities allocate resources by pre-established plans. There is underlying theoretical assumption behind this system:

1) assumption of absolute information. That is, central planning authorities possess complete correct information about all social economic activities and can control information variation in time, including conditions of material resources and human resources, technical feasibility, demands structure and etc... Accordingly, they can work out scientific plans and issue correct planning orders;

2) Assumption of single interest subject. Individual interest and social interest completely coincide and there is no separated interest subject and different value judgment [3];

3) Assumption of complete rationality. Based on obtained information, planners are able to make objective and correct judgment or decision from the overall situation of national economy. Planning system's effective performance and achievement of optimal resource allocation depend on whether it has satisfied those three premises mentioned above.

In early years of the new nation, single development goals, low economic level, simple economic structure, undeveloped social division and low-level, simple and equalized social demands greatly reduced the amount of information, which made it possible for planners to control the most basic information. Secondly, in terms of people who suffered long-term hardship of western powers and wars, it highly corresponded to their demand for security and stability to accelerate to establish industrial foundation for national dependence and social stability. For this strategic goal of giving priority to develop heavy industry, people were willing to contribute all economic surpluses even part of necessary products in a certain period. Last but no least, spirit of heroism and dedication inherited from war times, high political enthusiasm and cohesive force promoted by goals after people becoming the masters of country and justice, equal and pragmatic working styles of administrative authorities and party or political officers greatly reduced the operation costs of conventional system and improve the effectiveness. Planning system achieved such a remarkable system performance for the reason that it had satisfied three basic premises of information, incentive and economic rationality in particular social and historical conditions.

However, special period is impossible to continue for a long time. With the mass establishment of modern corporations which take machine production as technical basis and the expansion of production scale and productivity, allocating resources by planning system has encountered with the stubborn difference of information, incentive and planners' rationality.

From the perspective of information mechanism: firstly, planning management not only controls macro-level economic activities and meso-level economic activities of industries and regions but also directly intervenes microlevel economic activities, which involves corporations' routine business activities in the range of planning orders. Governmental policy has replaced the decision of individual and manufacturer. However, due to the deepening social 
division, large variation of supply and demand and wide and complex connection between producers and consumers, it is almost impossible for centralized planning authorities which take charge of various micro affairs to obtain all information required for smooth operation of economic system. Egon Nueberger, an American economist, said in Comparative economic systems that in the early 1960s, a major industrial corporation needed about 6 million operations within a year and 44 million information identification would be submitted to the superior which only took up 12 to $15 \%$ of all statistics collected by corporation. In 1962, there were about 46000 industrial corporations, 66000 transportation corporations, 11000 construction and design corporations, 50000 agricultural corporations, 600000 retail sites, 163000 public restaurants and 175000 warehouses in the Soviet Union [4]. Just imagine, the control over all operators' activities requires Soviet centralized planning authority to obtain such an enormous amount of information. Even it was able to obtain all necessary information, the cost would be infinite. Secondly, in addition to insufficient information, there also existed the problem of information distortion and delay which is related with the expansion of economic scale. In planning system, there is the lack of horizontal connections and effective feedback mechanism between producers and consumers. Economic information is transmitted lengthways along by the organization of planning grades. Conditions can be reported to the superior and transmitted to the inferior at different levels. Due to the narrow channel, there is frequent delays and congestion. Besides, the distortion is inevitable because of long transmission distance and multiple links. Taking micro subjects' subjective intent into consideration, the problems will become more serious. There was a ratchet effect in planned economy. For self-interest, corporations tended to conceal their actual productivity to ease the pressure of plans and to avoid the unfair punishment to effective performance; or for other interests beyond economic interest, including the promotion of corporations' status, individual administrative promotion or social honor, they chose falsify the yield and information. As a result, economic plans were often based on inadequate, inaccurate, even false and out-dated information, which caused decision-making mistakes and inefficiency in resource allocation.

From the perspective of incentive mechanism: planned economy takes conscious social people as a premise, emphasizes the overall interest of country or society, denies the interest difference between corporation and individual, eliminates people's motivation for economic self-interest and rejects the economic development promoted by self-interest. In the early stage of planned economy, individual and social demand structure is roughly identical; individual and social interest roughly coincides. High political enthusiasm and the dedication of heroism have become as a powerful source of economic development.However, after basically solving the problem of national security and stability, with the further development of economy the significance of selfinterest and individual value gradually emerges. Thus, the contradiction between self-interest and overall interest, partial interest and general interest has become more serious. Except administrative measures, planning system cannot provide proper means to solve the interest contradiction. For a long time, too much emphasis on social interest and ignorance of self-interest and partial interest; decrease of political mobilization ability; and serious separation between interests of corporations and individuals and their products and labor 
have decreased the enthusiasm, initiative and creativity of subjects. On the contrary, the phenomenon of laziness, falsification and opportunism become more and more serious. In order to solve the behaviors of opportunism and overcome the plan distortion and deviation caused by partial interests, the country has to pay a huge transaction cost including the supervise costs. With the decline of spiritual incentive, this kind of measure which depends on non-economic incentive to achieve economic activities' goal will take less impact on economic development.

From the perspective of planners' rationality: once technological variation and industrial evolution begin to develop, complex labor division and changeable industrial connections will break planners' limited rational boundary. Soviet planners supposed that in the first 25 years of implementing planned economy, the complexity of planning had increased 1600 times. Despite of the expansion of economic scale and the complexity of social economic structure exceed a certain degree, planners blindly manipulate management tasks beyond their ability. Even centralized authority is able to have a accurate and timely command of millions of changeable statistics in every corner of society and even they possess modern material and technological methods, it is still impossible for them to correctly deal with tremendous amount of information, to solve millions of even billions of equilibrium equations, to work out plans which cover everything and to transmit it to implementation departments in several days and months. In order to improve the scientificity of decision-making, in 1971 the 24th conference of Soviet Communist Party declared to establish automatic planning computing system on the basis of existed national computing network and communication network. Till early 1980s, although the technology of planning program had been greatly improved, it still didn't prevent the sharp drop of system effectiveness. Due to the asymmetry between information increment and planners' ability of rational stretch, planners are doomed to a failure in bringing all social economic activities into the range of system and operation. Larger scale of organization entity would contribute to more maladjustment in limited rationality. In addition, the plan is of strong subjectivity. Scientific plans depend on decision-makers' correct and clear understanding on internal links of complex economic phenomenon. However, due to planners' cognitive limitations, the decision-making errors and plans divorced from reality are inevitable.

On the one hand, with the expansion of economic scale, the information costs of planning system will increase to a high level. The differentiation of economic interests and the emergence of gap will cause a sharp increase of transaction costs such as moral hazard and opportunism. Eventually, the society cannot afford the heavy burden of institutional costs; on the other hand, rapid increase of information cause by expansion of economic scale will go far beyond the limitation of planners' information processing ability, which contributes to gradual decline in decision-making. The direct consequence is the decrease in the system effectiveness and a convert from rise to fall.

The article is the phased achievement of "Economic Analysis of the Public Economy Development" Project belonged to Shandong Social Science Planning Project and "Research on 'Insider Control' in System Transformation" Project belonged to Shandong Provincial Department of Education. 


\section{References}

1. Song T. Political Economics, Beijing: Renmin University of China Press, 2008.

2. Dong F. Re-interpretation of socialist economy, Tianjin Social Sciences, 1998, no. 3, pp. 5-11.

3. Wu J. China Economic Reform, Shanghai: Shanghai Far East Press, 2003.

4. Neuberger E., Duffy W. Comparative economic systems: a decision-making approach, Boston: Allyn and Bacon, 1976.

\section{Список литературы}

1. Song, T. Political Economics / Tao Song. - Beijing: Renmin University of China Press, 2008.

2. Dong, F. Re-Interpretation of Socialist Economy / Fuying Dong // Tianjin Social Sciences. -1998 . - No. 3. - P. $5-11$.

3. Wu, J. China Economic Reform / Jinglian Wu. - Shanghai: Shanghai Far East Press, 2003.

4. Neuberger, E. Comparative Economic Systems: A Decision-Making Approach / E. Neuberger, W. Duffy. - Boston: Allyn and Bacon, 1976.

\section{Переосмысление превратностей плановой экономики}

\section{Сай Сяосюй}

Школа экономики, Шаньдунский педагогический университет, 2. Цзинань, Китайская Народная Республика

Ключевыес слова: механизм информирования; механизм стимулирования; плановая экономика; рационализм планирующих организаций.

Аннотация: В Китае, большинство исследований по проблемам экономического планирования носят ограниченный характер в силу того, что в них основной акцент делается на недостатках плановой экономики, таких как отождествление государства и предприятия, незнание закона стоимости, уравниловка в распределении и т. п. Проблемы плановой экономики рассмотрены в контексте трех экономических характеристик: механизмов информирования и стимулирования, а также рационализма планирующих организаций. 